\title{
Sculptural Plasticity
}

Rowan Bailey

Plasticity (plasticité) inhabits a broad spectrum of disciplinary contexts. Its reception as a term in the worlds of philosophy, literature, and art is as an embedded aptitude within the thinking mind, derived from the Greek plassein, "to mould or form," as well as the register of transformation; of shifting states of matter, from the malleable to the ductile, the pliant to the adaptable. Plasticity is a carrier of material capabilities and form-evocations. Its semantic plurality means that it has multiple dimensions. As Catherine Malabou explains in What Should We Do with Our Brain?:

The concept of plasticity has an aesthetic dimension (sculpture, malleability), just as much as an ethical one (solicitude, treatment, help, repair, rescue) and a political one (responsibility in the double movement of the receiving and giving of form). It is therefore inevitable that at the horizon of the objective descriptions of brain plasticity stands questions concerning social life and being together. ${ }^{1}$

The reception of plasticity as an aesthetic dimension is linked to the sculptural transformations of our cognitive and phenomenological states as brainbodies in the world. The sculptural alludes to differing forms, the outcomes of which register an ongoing preoccupation with the ways in which ideas are material mutations of plasticity's agential power to act as the guarantor of inevitable change. This is also specific to a feminist materialist methodology where the epistemological framings of knowledge are shaped by bodies as sites of resistance to universalising ideologies. As part of the expanding languages of new materialism the term brainbody occupies the space of "experience-dependent plasticity." As Victoria Pitts-Taylor explains in her introduction to the edited book Mattering: Feminism, Science, and Materialism, the plasticity of the brain as "self-organizing and transformed by experience" ${ }^{\prime 2}$ has come to influence philosophically-orientated thinking. For 
example, rather than consider mind-brain as made up of neural networks subject only to the codifications of scientific empiricisms, discourses in analytic philosophy, consciousness studies, cultural studies, and feminist thought have sought to re-ignite embodied, embedded, and situated brain-bodily experiences. The neurobiological fundaments of brains as phenomena in the world are thus part of a call to rethink the "social in fleshy, biological and ecological terms, and allows the human (and non-human animal) to be considered in her physical, embodied, and experiential realities." 3 These realities thus challenge some of the historical preconceptions ascribed to the thinking mind through the entanglements between old and new materialisms in philosophy. As Pitts-Taylor explains: "New materialist thought decenters the intellectualist and discursive subject, linking the mind to the experiential, affective, phenomenological, and neurophysiological body."4 Such sentiments provide opportunities for engaging in materially discursive re-readings of plastic form-phenomena. For the purpose of my consideration of sculptural plasticity as an aesthetic dimension at work in the forms of experience-dependent plasticity, this essay presents new materialist instances of brainbody phenomena unfolding within different environmental scenographies. These phenomena provide insights into thinking with the plasticity of matter at the site of somatic vulnerabilities. The first registers Socrates's catalepsy through Hegel's attempts to situate this condition as a necessary stepping stone leading towards pure thought. I re-read this account alongside the experiential symptoms of post traumatic stress disorder (PTSD). Second, I turn to Sartre's account of nausea in his novel of the same name, first published in 1938, to expose a brain-bodily vulnerability generated by Antoine Roquentin's encounter with a pebble. This nonhuman iteration exposes the reader to an existential futurity - the death-drive of the plasticene - where plastics and plasticity are caught in a battle between the brain and the environment. I argue that the experiential modulation of sculptural plasticity is actually the manifestation of a fear of plastic's material resistance to change. As a transformative power 
and potential oceanic touchstone of ecological materialism, the plasticity of all life-forms are not only entangled and suffocated by the synthetic matter of the plastic ocean from below; they are also subjected to micro-plastics in the atmosphere. This is an imperceptible condition that nausea cannot register. Third, I account for Pierre Huyghe's recent installation at Skulptur Projekte Münster 2017. After ALife Ahead is the site for morphogenetic acts of cell and bacterial formation and self-generation. The intra-active entanglements between organic life forms and the climatic conditions of the physical environment in this installation calls for a materially-discursive practice of writing in, with, and through the brainbody, not as a phenomenologically grounded and/or embodied encounter with materiality, but rather as a dispersed act of sculptural thinking with plasticity in a time-based bio-technical system.

To begin with Socrates. But a Socrates labelled with a so-called "pathological" condition called catalepsy. ${ }^{5}$ As a paralysis of muscles in the body, a stiffening of limbs into fixed poses analogous to the plastic immobility of a statue, this neurological disorder has been the subject of great speculation and intrigue in readings of Socrates. From the Greek katalepsis meaning "seizing/grasping" catalepsy is a nervous disposition where bodily functions slow down. The neuronal disjunction between brain and body manifests the symptoms of psychomotor immobility. In Plato's Symposium catalepsy serves as a conversation point for an unfolding of Socrates in his absence. To consider the circulation of meanings generated around this condition it is necessary to register the reception of catalepsy within philosophy. The most startling instance can be found in Hegel's Lectures on the History of Philosophy, the beginnings of which are framed by his inaugural address at Heidelberg on 28 October $1816 .{ }^{6}$ Sarah Kofman also serves as an important voice in this rereading. In Socrates: Fictions of a Philosopher she observes Hegel's attempts to repurpose Socrates's "pathological condition" for the teleological ends of speculative philosophy. Building on this reading within the context of sculptural plasticity re-invests the brainbody as 
a situated and embodied site for the reoccurrence of traumatic episodes in an attempt to cognitively process lived experience. This exposes Socrates's vulnerability as a figure within the history of philosophy.

For Hegel, the purpose of the history of philosophy is to recognize that philosophy needs empirical forms through which to understand itself. These concrete determinants are subject to change over time through the cultural formations of knowledge. Socrates, the exemplar of all that is good about ancient Greece, thus serves as the conduit for thought's journey towards the absolute. Hegel introduces Socrates as "the great form" in Athens, "in whom the subjectivity of thought was brought to consciousness in a more definite and more thorough manner." ${ }^{\prime 8} \mathrm{He}$ is a figure in and of Greek antiquity and characterized by the classical ideal. Represented by the cultural forms of the period Socrates is born out of the soil of Greek life. He did not, asserts Hegel, "grow like a mushroom out of the earth." 9 There is no fungal network, no sharing of nutrients and information within an ecosystem, no breaking down of plant and animal debris to enrich this soil. The earth has been hardened for erecting self-made characters. Figure and ground are distinct entities. There is no mycological composting to this story. $^{10}$

In fact, there are at least two instances in Hegel's corpus where the sculptural formations of Socrates help to verify a specific reading of his cataleptic state. First, Hegel is clear to point out that Socrates was born in the fourth year of the $77^{\text {th }}$ Olympiad (469 B.C.) to a sculptor and a midwife. Sophroniscus, a stonemason, trained Socrates in the art of sculpture making. The draped Graces on the Acropolis are attributed to him. But Socrates preferred instead to follow philosophy and as the deliverer of ideas embraces the specialist midwifery skills of his mother, Phaenarete. Hegel does not explicitly say this of course. ${ }^{11}$ Second, Hegel reinforces the significance of statuary as a form-manifestation specific to the Greeks. "Individual character" ("plastic individuality") is grown out of the achievements of fifth- 
century Athens, an epoch of economic and cultural growth. In the Lectures on Fine Art, first delivered at Berlin in 1820-1821, Hegel considers the Periclean age as rich with self-made characters: "Pericles himself, Phidias, Plato, Sophocles above all, Thucydides too, Xenophon, Socrates - each of them his own sort, unimpaired by another's; all of them are out-and-out artists by nature, ideal artists shaping themselves, individuals of a single cast, works of art standing there like immortal and deathless images of the gods, in which there is nothing temporal and doomed." 12 In The Future of Hegel: Plasticity, Temporality, Dialectic, Malabou considers plasticity as an operating function within Hegel's system. As an entry into the contingent formations of the past, plasticity is both the maker and marker of futurity: the condition for and disturbance to speculative philosophy. Plasticity is the receiver, producer, and annihilator of form. The role of the plastic subject is described as a middle term situated (teleologically) between the plastic art of sculpture and the emergence of "philosophical plasticity."13 As a condition which makes possible the dialectical progress of Hegel's system, plasticity is an essential feature of the development of self-consciousness. She writes:

The dialectical process is "plastic" because, as it unfolds, it makes links between the opposing moments of total immobility (the "fixed") and vacuity ("dissolution"), and then links both in the vitality of the whole, a whole which, reconciling these two extremes, is itself the union of resistance (Widerstand) and fluidity (Flüssigkeit). ${ }^{14}$

In this respect, and for Hegel in particular, Socrates is caught up in this plastic process. The cataleptic moments he falls into are exemplars of a dialectical unfolding in and of the brainbody itself. Three pages into the section on Socrates in the Lectures on the History of Philosophy Hegel takes us into Plato's Symposium to speculate on the significance of "magnetic somnambulism." It is with Socrates's military duty in the Peloponnesian war "the war that led to the dissolution of Greek life" "thinking consciousness." The famous scene in the Symposium is recounted by Alcibiades 
who describes how, in one particular campaign, Socrates stood on one spot for one day and one night in an ecstatic state of immobility, much to the amusement of the soldiers, who eventually bed down underneath the stars with him. This is an important moment for Hegel's articulation of what thinking has to do to break from the habit formations of the diseased mind-body: "this physical setting free of the inward abstract self from the concrete bodily existence of the individual, we have, in outward manifestation, a proof of how the depths of his mind worked within him." 16 The cataleptic repetition, the habit-formation of disassociating consciousness from the affective dimensions of bodily experience, is, in Kofman's reading of Hegel, the repetition which needs to be replayed until thought and the body are no longer inter-dependent. She writes: "One becomes pure thought, pure interiority freed from all bodily attachments, by repeatedly making the effort to pull oneself away from corporeity in order to think." 17

What if one were to consider catalepsy as a brainbody phenomenon out of which neurology and speculative philosophy collide? How is sculptural plasticity formed and re-formed by these entanglements? For Hegel's speculative philosophy it is necessary for Socrates's immobile state to represent an effort to move mind beyond the limitations of the sensuous body. The pathological condition of "ecstatic immobility" is actually Socrates's way of rehearsing the journey towards pure thought. As Kofman explains: "Thought has merely to take on the habit of thinking - repeating its moments of reappropriating ecstasy, its moments of recollection - in order to find health at the end of its road of dialectical development." 18 A deeper look into the neurological symptoms of catalepsy as a reoccurring post-traumatic stress disorder tells us something about the psychomotor processing of the brainbody. Why, for example, does Socrates fall into a state of immobility at the height of a military campaign? And why is this event not the focal point around which further reflections on 
Socrates's character in Hegel's reading are generated? This bypassing of the narrative unfolding of catalepsy as a neurological phenomenon in the Symposium is the entry point for a new materialist reader.

Plato's Symposium begins with a hangover. We are in $416 \mathrm{BC}$, the day after the celebratory feast of Agathon's victory at the Lenaia. ${ }^{19}$ Pausanias and Alcibiades have been partying too hard. Socrates has not been to the celebrations the day before. He does not like crowds. But he has since washed and is heading over to Agathon's for dinner. On route he bumps into Aristodemus and invites him along. They head off together. Agathon welcomes Aristodemus into his home. Socrates is not with him. Agathon sends a servant to fetch Socrates and after a time they return to explain that Socrates has retreated into the neighbour's porch: "there he was standing and refusing to come in."20 "Let him alone," says Aristodemus, "it is a habit he has. Occasionally he turns aside, anywhere at random, and there he stands. He will be here presently. I expect. So do not disturb him; let him be." ${ }^{21}$ So, they start dinner without him.

Socrates's absence in this introductory play of events can be read in many ways. From a pathological point of view Socrates's fear of crowds may be a form of claustrophobia or social anxiety. He avoids the celebrations from the night before because of this. The threshold of the doorway is also a space where the more anxiously minded may be driven. Aristodemus speaks of Socrates's habit-formations with a depth of understanding. He has seen this before and knows what is best: "do not disturb him; let him be."22 For the contemporary psychoanalytic-neurologically minded reader, Socrates may indeed be a posttraumatic stress sufferer, brought about as a result of various military campaigns under service. ${ }^{23}$ Within the Symposium Alcibiades provides eyewitness accounts of Socrates in the battles of Potidaea (432 BC) and Delium (424 BC), including the famous scene at Potidaea where "immersed in some problem at dawn, he stood in the same spot considering it; and 
when he found it a tough one, he would not give it up but stood there trying." 24 The general reception in Plato's accounts of Socrates' military service is one of endurance despite great physical and psychological stress. We read about deprivations and hardships - lack of food, extreme cold, long term deployments and redeployments - all of which Socrates seems to withstand..$^{25}$

When a reader tracks these instances in the Symposium there are clues to suggest that Socrates, whilst certainly enduring the horrors of war, does not necessarily overcome them. The cataleptic scene at Potidaea is not in isolation from the horrors of Delium, as reported by Thucydides's History of the Peloponnesian War and registered in the Symposium. ${ }^{26}$ In the middle of a hoplite battle, Athenians mistake the enemy and start to kill each other. According to Alcibiades, Socrates was caught up in this "friendly fire" and describes his movement through the battle as if he were wandering about town. Quoting from Aristophanes's Clouds Alcibiades remarks how, in the utter chaos, Socrates simply "stepped along, as his wont is in our streets, 'strutting like a proud marsh-goose, with ever a side-long glance,' turning a calm sidelong look on friend and foe alike, and convincing anyone even from afar that whoever cares to touch this person will find he can put up a stout enough defence." ${ }^{27}$ How is it possible not to recognize in these scenes shock, bewilderment, and above all fear, and why wouldn't the accumulation of these experiences not lead to the traumatic resurfacing of psychological stress in Socrates as part of his cataleptic symptoms? Side-long glances do not meet the enemy head-on, but rather, deliberately avoid being seen, and perhaps, in an attempt to avoid the gaze of the other, one can see that this "stepping along" is an awkward and uncertain goose-like strut. On dry land geese do not glide or fly or speed their way across terrain. They "waddle" with short steps, in a clumsy, swaying motion. A tottering and not a strutting. Socrates is wobbling in a battle where everyone is subject to being mistaken for the enemy. 
The chronology of these events - first we take Potidaea and then Delium - exposes an experience of "war trauma” overturned by Hegel's philosophical enterprise. If Socrates's cataleptic condition is a synaptic trauma that resurfaces without warning, it is certainly not part of the dominant narrative put forward by Hegel in his Lectures on the History of Philosophy. Hegel builds a persona for Socrates which suits his speculative philosophy. Whereas we see Socrates's catalepsy as the psychomotor immobility of the brainbody brought on by a reoccurring trauma, Hegel shapes a story of this condition from out of familial legacies. This biographical inheritance of Socrates is the mould out of which the cataleptic state is born. For Malabou in The New Wounded: From Neurosis to Brain Damage, the concept of post-traumatic stress disorder (PTSD) applies to all trauma cases: "the catastrophic event is itself void of sense and traumatic experience is first and always an experience of the absence of sense." 28 This extends to socio-political trauma. Hegel's reading of Socrates's cataleptic state neglects the experiences of war that contextualise his symptoms. In effect, the very "absence of sense" which Hegel says is the necessary habit formation that must be repeated until speculative philosophy knows how to process itself, is also, at the same time, the catastrophe, the rupturing of the transference between the "receiving and giving of form." For example, in Ontology of the Accident: An Essay in Destructive Plasticity, Malabou explains how "explosive" or "destructive" plasticity undoes the capacity for reparation. It is a "form" of plasticity that is denied an identity in Greek mythology, forever doomed in the endless mutations of polymorphism. Socrates's brainbody is, like Greek mythology, the site of vulnerability. Traumas are processed through the reshaping of experience, again and again, each time forming and deforming themselves anew. Hegel's reading of catalepsy is a desire to be done with such fixations. What is the beyond of pure thought if not the annihilation of all form-phenomena? As Malabou explains, "destructive plasticity" is that which "sculpts by annihilating precisely at the point where the repertory of 
viable forms has reached exhaustion and has nothing else to propose." 29 This is the annihilation of Socrates as a brainbody shaped out of experience-dependent plasticity. Such a teleological end rids catalepsy of its psychological wounds. The end of plasticity, as a transformative process, is the teleological end of speculative philosophy, which we know is, despite its ambitions, doomed to repeat itself in the re-reading of what has come to pass. Hegel's need for catalepsy to be the dress rehearsal of Socrates's own death (and ancient Greece) is thus integral to the speculative logic of his system. In effect, catalepsy cannot be anything but a rehearsal of what we know will become the opening night of Socrates's fate.

From a new materialist point of view catalepsy is part of the phenomena of the brainbody's role as carrier of plasticity and its properties. Between the environment and the material interiorities of experience, the synaptic conditions of thinking are new acts of sculptural modulation. The self-organisation of brainbodies processing traumatic experience is as significant as the rupture itself. Socrates may indeed be stuck in acts of habit formation, but this is also the nervous system of the brainbody healing itself. In the aftermath of "shutting down" Socrates is consistent in his efforts to pursue dialogical processes. He is never not thinking with others, never not pursuing the "double movement of the receiving and giving of form." 30 Indeed, the social "thinking-with" to which Socrates repeatedly returns, in the aftermath of the cataleptic rupture, is always a re-entry, a crossing of the threshold into the collective cognitive spaces of exchange. This is his "talking-cure" in which we are all implicated.

Sartre's novel Nausea circulates around a pebble. ${ }^{31}$ First published in 1938 it tells the story of Antoine Roquentin, a thirty-year-old academic about to embark on a write up of his research project on the eighteenth century political figure, the Marquis de Rollebon, an aristocrat living during the French revolution. Bored and listless with the historical research he has yet to complete, Roquentin is confronted with a reoccurring physical sensation of 
sickness. This feeling is triggered by the "natural" formation of a pebble and prompts him to write a diary, to try to get to grips with this transformative brainbodily change. To write through this change, to which all the associated themes of existentialism arise - anxiety, suffering, self-deception, and freedom - Roquentin, in pursuit of classification and determination discovers that the so-called "essences" of the objects he seeks to grasp conceptually, are obscure, indistinct, and without meaning. Roquentin's inability to comprehend his experience generates a fear and anxiety about touching these objects. His free will is challenged by his own failure to make sense of the pebble in the palm of his hand.

The beach scene at the beginning of Nausea, where material contingency gives rise to the intense bodily experience of disgust, is, I will argue, a perceptual articulation of the battle between experience-dependent plasticity and non-human formations. On the one hand, Roquentin's situated and phenomenologically determined experience is shaped by the effects of an eco-system. With the changing tides of the ocean pebbles are transformative objects. They are geological phenomena caught up in an ongoing process of material change. In this respect, they are the exemplars of sculptural plasticity. They are formed and reformed by the environments they inhabit. The pebble is the material effect of ongoing geological processes and forces. On the other hand, Roquentin rejects this capacity for continuous transformation, is incapable of receiving this formation, and as a stress response, a psychopathology of feeling generates itself in and through his brainbody as a panic attack. The symptoms of nausea - both psychic and physical - manifest as an experience without a clear reference point. I want to consider how the bodily feeling of disgust "full of lynoh or warm milk"32 engulfed in a "frothy water," bubbling in the mouth, is actually a fear of futurity brought about by synthetic plastic waste. This requires an imaginative leap into three interlinked and operant functions within this brainbody phenomenon. First, I will consider Sartre's own phobias and anxieties with the ocean as the site for subconscious monstrosities. Second, I will 
account for nausea as an experience-dependent mechanism at work in the nervous system of our brainbodies. Third, I will consider how the concept of plasticity and the synthetics of plastic waste are part of the ecological entanglements of our times. These form the storytelling practices of meaning-making where materialisms are not simply re-positioned in the ocean scenes of environmental catastrophe, but serve as the opening towards a necessary rethinking of new matterings in the world, including the perceptible and imperceptible relations they give rise to.

One could say that the environmental crisis of the plastic ocean is akin to Sartre's own extreme fear and anxiety of the surface structures of crustacea. Sartre had a phobia of any tentacular powers, especially those Donna Haraway calls the "webs of speculative fabulation, speculative feminism, science fiction, and scientific fact." 33 Sartre was terrified of marine life, especially crabs and lobsters. As a result, he would rarely swim in the ocean and often spoke of his fear of sea-monsters reaching out to drag him down into the depths. According to Eric H. du Plessis in "Sartre, Existentialism and Panic Attacks" the existentialist was known to run from the sea in a panic and this phobia entered into his writings, including Nausea ${ }^{34}$ Moreover, as the result of a mescaline injection under the medical supervision of Dr. Lagache, at Saint-Anne Hospital in Paris in 1948, Sartre's phobias exacerbated with hallucinatory scenes of "swarms of giant crabs and even a demented octopus." 35 Sartre apparently had flashbacks which continued for over a year after this incident. As a contributory factor to a growing set of triggers for Sartre's panic attacks, he developed an addiction to prescription drugs - both highs and lows/amphetamines and barbiturates - which essentially reinforced feelings of despair and alienation. The thing about pebbles and crabs is that under foot they can be mistaken for one another.

In terms of thinking about nausea as a defence mechanism at work in the nervous system of our brainbodies, the attachment of psychic encounters with external stimuli re- 
register physiological reactions in an unfolding of experience-dependent plasticity. Here is the pebble scene in Nausea:

On Saturday the children were playing ducks and drakes, and I wanted to throw a pebble into the sea like them. At that moment I stopped, dropped the pebble and walked away. I imagine I must have looked rather bewildered, because the children laughed behind my back.

So much for the exterior. What happened inside me didn't leave any clear traces. There was something which I saw and which disgusted me, but I no longer know whether I was looking at the sea or at the pebble. It was a flat pebble, completely dry on one side, wet and muddy on the other. I held it by the edges, with my fingers wide apart to avoid getting them dirty.

Now I see; I remember better what I felt the other day on the sea-shore when I was holding that pebble. It was a sort of sweet disgust. How unpleasant it was! And it came from the pebble, I'm sure of that, it passed from the pebble into my hands. Yes, that's it, that's exactly it: a sort of nausea in the hands. ${ }^{36}$

As the study of the workings of human consciousness and the experiences they give rise to, phenomenology, in this context, is part of a growing awareness of objects and their agential capacity to move the self beyond its ego-positioning as a consistent identity. The feeling of "sweet disgust" as a "nausea in the hands" is actually a physiological state where affectivity becomes the mechanism for negotiating the unbearable thought that there is something unresolvable about existence. The contingency of which is further catalysed by the pebble. Physiological affect is projected onto the object. It is the pebble that causes such sickness. The three passages above outline a process where thinking through the phenomena of the 
lived experience is itself an exercise in material translation, where the perceptual awareness of the encounter shifts focus to the temporally reflective aftermath of the writing process.

First, Roquentin is part of a scene with others. The small children he watches and seeks to participate with is cut through by the pebble's material-mineral properties. It is more than a functionary for the game being played. Second, the pebble shifts the context into the space of its own material contingency and reveals itself as a disruptor to a perceptual fielding of the brainbody and its attempts to ascribe order and meaning to experience. Roquentin's failure to situate and place the pebble within a system of relations creates an intense bodily experience. This is not an active thinking that controls the world through the processes of identification. Rather, the physiological bodily encounter is without reference point. The feeling of sickness is unstable and it is the pebble as contingent matter that activates the disgust. This bodily immersion, as a pull into the space of non-mastery, uncertainty, ambiguity, and disconnection, is no longer a feeling associated with a scene of children playing ducks and drakes. The writing through of the experience reveals the encounter as a spatial relation where the pebble, in all of its material agency, transforms the brainbody into a porous membrane. No immobile statuary is present in this intra-active scene.

There is something reassuring about this reaction to external stimuli including the revelations they bring as psychic disturbances to the intense perceptions of bodily existence. Nausea is a pure apprehension spoken by the brainbody. The sculptural plasticity of the pebble as material trigger for an intra-action with the brainbody and the ecologies of the environment is an awakening. To have such a visceral response to this form, to defend against it, to feel like it cannot be assimilated, received, and fully incorporated, is an extreme physiological-psychic awareness of vulnerability. There are forces at work in this materialisation of difference. Human and nonhuman entanglements are caught up in a seasickness of perceptible dislocations. 
The tension between the concept of plasticity - as a real lived experience of the existential anxiety towards the flux of transformation and change - and plastic - as a resistant synthetic material - is a different kind of encounter between the human and the non-human. Being confronted with what is fixed and stubborn, rather than mutable and malleable, restricts the imaginary apparatus of the brainbody. As Heather Davis explains in "Life \& Death in the Anthropocene: A Short History of Plastic":

Plastic, once it has been formed through the miracles of the chemical industry, remains recalcitrant both to biological process as well as human creativity. It is the materialization of the horror of identity, of the stability of form, of a futurity without change. ${ }^{37}$

As a bodily response, nausea, in the context of Sartre's story, does not readily receive this condition. Rather, the "stability of form, of a futurity without change" activates a dumbing and numbing down of the perceptual awareness of dislocation, much like the effects of barbiturates in Sartre's brainbody. Imperceptible like small sub-therapeutic pharmaceutical micro-doses of psilocybin. We have entered into a plastisphere where we are not even physiologically conscious of the micro-plastics in our own nervous systems. ${ }^{38}$ Classified by the U.S. Oceanic \& Atmospheric Administration as being less than 5mm in diameter, microplastics and their operations are the exemplar of porous brainbody relations. Whereas Roquentin was able to handle his material encounter with the changing tides of the universe, allow his body to viscerally reject the pebble to bring it back to the humanist concerns of an existential crisis, our engagement with micro-plastic particles and micro-organic communities in places like the Great Pacific Garbage Patch ${ }^{39}$ is truly a post-humanist condition.

For example, as Heather Davis explains in "Imperceptibility and Accumulation: Political Strategies of Plastic" 40 the morphologies that have been generated out of plastic 
effects are calling for us to "reimagine the futures we are ushering in, demanding new strategies of extinction and survival." ${ }^{41}$ Rather than simply reinforce the feeling of anxiety and fear, hopelessness and meaninglessness in an era of environmental catastrophe, we must negotiate and re-think our relationship to imperceptible change. This requires a thinkingthrough of what "imperceptibility" might mean for living with toxicity, including our relationship as brainbodies with new life forms in the plastisphere. For Davis, the effects of plastic are delayed, dispersed, and accumulate over time. Like the endless polymorphism of ancient Greek mythology, we must embrace "the lesson of shape-shifting, of assuming identities that defy coherent forms and change with and in response to particular contexts - to abandon ontology and its promises. $" 42$ In this respect, imperceptibility is against the processes of identification - under the political categories of identity - and is instead "about creating structures and ways of being that are at once immediately apparent, at once immediately understood, but yet reveal nothing, containing no truth, no depth. Surface all the way through, hidden in plain sight." ${ }^{\prime 3}$ The porosity of this way of thinking and experiencing plastics effects is part of a future consideration of the ecologies of life forms generated out of the plastisphere. Davis writes:

These complex bacterial societies may flourish on their synthetic surfaces, eating each other, mutating and evolving, developing into complex organisms entirely dependent on vast sources of energy unlocked by carbon and wholly adapted to the acidic oceans in which they float. Just as plastics are inadvertently creating all kinds of new worlds such as the plastisphere in order to move effectively, we must learn to accept strange life forms, both human and nonhuman. ${ }^{44}$

In the future, it may be that the toxicity of our times induces ongoing vomiting, a rejection of the poisonous forms within us. But it is likely that the micro-plastics we have incorporated will become part of a psychopathology of imperceptible feeling within us. For Sartre, perhaps 
the fear of the plastic ocean and exposure to micro-plastics is too much of a futuristic registration, triggered by the surface of an ocean pebble and the depths of what lies beneath the water: "And under the water? Haven't you thought about what there may be under the water? A monster? A huge carapace, half embedded in the mud? A dozen pairs of claws slowly furrow the slime. The monster raises itself a little, every now and then. At the bottom of the water." ${ }^{45}$ Mineral forms and critters occupy the same space. We should not neglect to notice that the crab and the lobster are perhaps the "companion species"46 of Sartre's autobiography. In Words, first published in 1963, Sartre revisits his childhood. Feeling excluded as a child for being sickly in appearance, "a weakling who interested no one," he retreats from himself into the space of writing and is transformed into the shapes of his fears: "What then issued from my pen - an octopus with fiery eyes, a twenty-ton crustacean, or a giant talking-spider - was myself; a childish monster." ${ }^{\text {47 }}$ Our toxic nausea of future vulnerabilities will be part of new brainbodily experiences, physiologies of encounter that are gut bound and indigestible. In the plastisphere of these relations we will carry these life forms within us, be transformed by them. How we think inside these "bacterial societies" requires journeys with and through the plastic terrain of embedded and embodied phenomena within us.

As a final and concluding attempt to consider how the navigation through sculptural plasticity exists in the atmosphere of our times, I want to present a scenography that takes the form of an installation. In 2017, the fifth incarnation of Skulptur Projekte (Sculpture Projects Münster) - a major exhibition of sculpture in the city of Münster, Germany, taking place every ten years - featured a "time-based bio-technical system." Pierre Huyghe's After Alife Ahead (2017) occupied a former ice rink within which was constructed a symbiotic environment. A topology of relations organically evolved over a four-month period. This environment, where life forms cohabited and evolved in a state of "inter-dependence," is, I 
hope to show, part of the "experience-dependent plasticity" that has preoccupied this essay's account of "sculptural plasticity" as an aesthetic dimension within the semantically porous and plural field of the brainbody. For Hugyhe, the bio-technical topology of this system is not about the "inter-connectivity" of all things, but rather the general "indeterminacy," “indifference," “indiscernibility," "unpredictability," and "unintentionality" of all phenomena. ${ }^{48}$ These are the glossary catch-phrases that accompany Hugyhe's diagrammatic mapping of the installation. A space where the bio-technic system of life forces intra-act. The ongoing "displacing experiences" of agential possibility.

My visitor experience of this site took place on the last weekend of Skulptur Projekte. This was my second visit to Münster; the first took place in August 2017, in a flurry, rushing from brainbody yogic meditations at a retreat and the shock and horror of a busy and chaotic documenta 14. Tired and fatigued, irritated that I had wrong-routed myself through these events - the meditation should have come last - I searched high and low for Huyghe's ice rink and could not locate it. I kept losing myself. I felt indifferent to sculpture. I was not ready to receive. So, I returned to Münster in October to experience After Alife Ahead before it disappeared. I took a flight from Manchester to Düsseldorf, a train from Düsseldorf to Münster, a taxi to the site, to stand in a queue. It is raining hard. I feel cold and miserable. And then, I start to converse with the person beside me. He kindly offers to share his umbrella. He tells me he is undertaking a $\mathrm{PhD}$ in bio-technical systems. We talk about systems. He inhabits a language and world unfamiliar to me. I desire to know what he knows. He talks about teaching " $R$ " language and tells me he is studying at Jena on an exchange. He will finish his PhD in Hong Kong. He also tells me that he has lived away from home for 12 years. His mother has spent three months travelling around the United States in her retirement. I tell him that Hegel was at Jena and was a systems builder. He doesn't seem impressed. The research institute he is a member of has a very long name. I later find out that 
he is at the Leibniz Institute for Natural Product Research and Infection Biology, researching into natural products from micro-organisms to the infection biology of pathogenic fungi. We eventually enter the ice-rink. He pulls out a sophisticated camera and promptly starts to take what I imagine will be exquisite photographs.

The concrete floor of the ice rink is dug out; a rubber sheet geometry of triangles and triangulations, pyramidal structures reoccur as sculptural motifs, including the motorized ceiling, an automated opening triggered by algorithms that respond to changing vitalities in the space. The surface concrete is cut by an ostomachion logic pattern. Information from an incubator containing cancer cells initiate the formation of new pyramids indiscernible to the naked eye, but brought into appearance with the aid of an augmented reality app. The life levels of the space - generated by visitors and their production of carbon dioxide reproduces the cancer cells. The metastasis of the cells hover below the ceiling as virtualaugmented forms. They are inverted physical pyramids. Other life forms include an aquarium containing shells the surface patterns of which trigger a musical score. These sounds cause the transparency of the glass tank to shift triggering parts of the ceiling to open and close. Algae and bacteria grow on puddles of water generated by rain, wind and natural light entering into the space at regular intervals. A bee hive stands in one corner. It is a Paleolithic sculpture-figure, shaped out of found clay. Bee behavior is continuously detected by infra-red rays. The key materials that make up this system thus include: concrete, a game of logic (otherwise known as the Archimedes box in Latin), ammoniac (gum resin), sand, clay, phreatic water (ground water), bacteria, algae, bees, chimera peacocks, aquarium, black switchable glass, Conus textile (a venomous species of snail), GLoFish, crab, incubator, human cancer cells, genetic algorithms, augmented reality, automated ceiling structure, rain. The technologies of this system respond to changing states of matter. As the conditions of the space undergo transformation the algorithms alter and adapt. 
There are visual oddities in this space. Visitors walk around and through this planetary landscape. They are immersed but the open drying umbrellas at the periphery are telling. The PhD student later tells me that he has spotted two bees in the hives. We discuss how they might be surviving in this environment. He says it would have been better to have left this site for a year. ${ }^{49}$ Then we could see more of its inhabitants. He thinks cockroaches and rats would also be living here. As an "experience-dependent" installation, these cells, organisms, and life forms have evolved within, and as, a necessary contribution to the changing states of the bio-technical system. Even the brainbodies of the visitors arriving for an aesthetic experience play a role. We are part of the intra-acting system of dependencies and as vulnerabilities, because there are no known survival strategies for this particular environment. After Alife Ahead is what Isabelle Stengers might describe as that which evolves out of Gaia's intrusion, in spite of us. ${ }^{50}$ Perhaps this is the earth out of which Socrates could grow as a mushroom.

University of Huddersfield

\section{Notes}

1. Malabou, What Should We Do with Our Brain, 30.

2. Pitts-Taylor, Mattering, 6 .

3. Pitts-Taylor, Mattering, 6-7.

4. Pitts-Taylor, Mattering, 7.

5. References to Socrates's catalepsy are gleaned from Plato's Symposium. Plato, Plato in Twelve Volumes, Vol. 9, 174d5-175c5 and 198c5 respectively.

6. Hegel's Lectures on the History of Philosophy (Geschichte der Philosophie) were published in 1833-1836 as part of Hegel's Werke (volumes 13-15) and edited by one of his 
students Karl Ludwig Michelet. The volumes are an assemblage of notebooks, student lecture notes, and writings by Hegel.

7. Kofman, Socrates, 66-70.

8. Hegel, Lectures on the History of Philosophy, 385.

9. Hegel, Lectures on the History of Philosophy, 385

10. For a more detailed account of composting as a new materialist way of thinking about the mattering of history, see Haraway, "Chapter 2: Tenatacular Thinking."

11. But many others have. See in particular, Jacques Derrida's reading of Plato's Timaeus in Derrida, On the Name.

12. Hegel, Aesthetics, Vol. 2, 719-20.

13. Malabou, The Future of Hegel Plasticity, Temporality and Dialectic, 10.

14. Malabou, The Future of Hegel Plasticity, Temporality and Dialectic, 12.

15. Hegel, Lectures on the History of Philosophy, 390.

16. Hegel, Lectures on the History of Philosophy, 391.

17. Kofman, Socrates: Fictions of a Philosopher, 68.

18. Kofman, Socrates: Fictions of a Philosopher, 66.

19. The Lenaia was a festival in ancient Athens and part of the winter festival cycle. Processions, theatrical performances, private banquets, and ecstatic revelries were part of the January event.

20. Plato, Plato in Twelve Volumes, Vol. 9, [175a].

21. Plato, Plato in Twelve Volumes, Vol. 9, [175b].

22. Plato, Plato in Twelve Volumes, Vol. 9, [175b].

23. See in particular, Monoson, "Socrates' Military Service." 
24. Plato, Plato in Twelve Volumes, Vol. 9, 220c-d. The siege of Potidaea is one of the key conflicts which initiated the Peloponnesian War and led to the Battle of Delium. Alcibiades's account also includes the saving of his life by Socrates during this battle.

25. Plato, Plato in Twelve Volumes, Vol. 9, 220a-e.

26. Plato, Plato in Twelve Volumes, Vol. 9, 221b.

27. Plato, Plato in Twelve Volumes, Vol. 9, 22b; citing Clouds 362. For an excellent account of the historical details of these wars, including the references to Socrates involvement in them, see Monoson, "Chapter Six: Socrates in Combat."

28. Malabou, The New Wounded, 155.

29. Malabou, The Ontology of the Accident, 54.

30. Malabou, What Should We Do with Our Brain?, 30.

31. Sartre, Nausea.

32. Sartre, Nausea, 14.

33. Haraway “Anthropocene, Captialocene, Plantationocene, Chthulucene," 159-65, 160.

34. Du Plessis, "Sartre, Existentialism and Panic Attacks," 63-68.

35. Du Plessis, "Sartre, Existentialism and Panic Attacks," 66.

36. Sartre, Nausea, 9-10, 22.

37. Davis, "Life \& Death in the Anthropocene," 353.

38. This is a term coined by marine biologists to describe the formation of new micro-organic communities from out of the debris that is the plastic ocean.

39. The patch is approximately 386,000 square miles at a periphery of $1,351,000$ square miles. See Milman, “'Great Pacific Garbage Patch’ far bigger than imagined.”

40. Davis, "Imperceptibility and Accumulation." See also Gabrys, Hawkins and Michael, eds., Accumulation. 
41. Davis, "Imperceptibility and Accumulation," 189.

42. Davis, "Imperceptibility and Accumulation," 190.

43. Davis, "Imperceptibility and Accumulation," 190.

44. Davis, "Imperceptibility and Accumulation," 191-92.

45. Sartre, Nausea, 116.

46. I refer to "critter" and "companion species" in Donna Haraway's sense of the terms. See Haraway, The Companion Species Manifesto and When Species Meet.

47. Sartre, Words, 97.

48. For an account of topology and topological systems in the body of Huyghe's work see Barikin, Parallel Presents.

49. This is, I speculate, an unknown. And now, impossible. After ALife Ahead always intended to be dismantled after the end of Skulptur Projekte.

50. See Stengers, In Catastrophic Times.

\section{Bibliography}

Barikin, Ameilia. Parallel Presents: The Art of Pierre Huyghe. Cambridge; MA: MIT Press, 2012.

Davis, Heather. "Imperceptibility and Accumulation: Political Strategies of Plastic." Camera Obscura 31(2(92)) (2016): 187-93.

Davis, Heather. "Life \& Death in the Anthropocene: A Short History of Plastic." In Art in the Anthropocene: Encounters Among Aesthetics, Politics, Environments and Epistemologies, edited by Heather Davis and Etienne Turpin, 347-58. London: Open Humanities Press, 2015. 
Derrida, Jacques. On the Name. Translated by Ian McLeod. Stanford, California: Stanford University Press, 1995.

Du Plessis, Eric H. "Sartre, Existentialism and Panic Attacks." The Linacre Quarterly 59(2) (May 1992): 63-68.

Gabrys, Jennifer, Gay Hawkins, and Mike Michael, eds. Accumulation: The Material Politics of Plastic. London and New York: Routledge, 2013.

Haraway, Donna. "Anthropocene, Captialocene, Plantationocene, Chthulucene: Making Kin.” Environmental Humanities 6 (2015): 159-65.

Haraway, Donna. “Chapter 2: Tenatacular Thinking: Anthropocene, Capitalocene, Chtulucene.” In Staying with the Trouble: Making Kin in the Chthulucene, 30-57. Durham: Duke University Press, 2016.

Haraway, Donna. The Companion Species Manifesto: Dogs, People and Significant Otherness. Chicago: Prickly Paradigm Press, 2003.

Haraway, Donna. When Species Meet. Minnesota: University of Minnesota Press, 2007.

Hegel, Georg W. F. Aesthetics: Lectures on Fine Art. Vol. 2. Translated by T. M. Knox. Oxford: Clarendon Press, 1975.

Hegel, W. F. Georg. Lectures on the History of Philosophy. Translated by E.S. Haldane. Nebraska: University of Nebraska Press, Bison Book Edition, 1995.

Kofman, Sarah. Socrates: Fictions of a Philosopher. Translated by Catherine Porter. London: The Athlone Press, 1998.

Sartre, Jean-Paul. Words. Translated by Irene Clephane. London: Penguin Books, 1967. Stengers, Isabelle. In Catastrophic Times: Resisting the Coming Barbarism. London: Open Humanities Press, 2015. 
Malabou, Catherine. The Future of Hegel: Plasticity, Temporality and Dialectic. Translated by Lisabeth During. London and New York: Routledge, Taylor and Francis Group, 2005.

Malabou, Catherine. The New Wounded: From Neurosis to Brain Damage. Translated by Steven Miller. New York: Fordham University Press, 2012.

Malabou, Catherine. The Ontology of the Accident: An Essay on Destructive Plasticity. Translated by Carolyn Shread. Cambridge: Polity Press, 2012.

Malabou, Catherine. What Should We Do with Our Brain? Translated by Sebastian Rand. New York: Fordham University Press, 2008.

Milman, Oliver. “'Great Pacific Garbage Patch' far bigger than imagined, aerial survey shows." The Guardian, October 4, 2016.

Monoson, S. Sara. "Chapter Six: Socrates in Combat: Trauma and Resilience in Plato's Political Theory." In Combat Trauma and Ancient Greeks, edited by Peter Meineck and David Konstan, 131-62. New York: Palgrave Macmillan, 2014.

Monoson, S. Sara. “Socrates’ Military Service.” In Our Ancient Wars: Rethinking War through the Classics, edited by Victor Caston and Silke-Maria Weineck, 96-117. Michigan: University of Michigan Press, 2016.

Pitts-Taylor, Victoria. Mattering: Feminism, Science and Materialism. New York; London: NYU Press, 2016.

Plato. Plato in Twelve Volumes. Translated by Harold N. Fowler. Cambridge, MA: Harvard University Press; London: William Heinemann Ltd., 1925.

Sartre, Jean-Paul. Nausea. London: Penguin Books, 1965. 